\title{
Analisis Kualitas Website Menggunakan Metode Webqual 4.0 Studi Kasus: MyBest E-learning System UBSI.
}

\author{
Indah Purwandani ${ }^{1}$, Nurfia Oktaviani Syamsiah ${ }^{2}$ \\ Sistem Informasi Akuntansi Akuntansi Kampus Jakarta ${ }^{2} /$ Fakultas Teknik dan Informatika ${ }^{1}$ \\ Sistem Informasi Akuntansi Akuntansi Kampus Kota Pontianak ${ }^{1 / F a k u l t a s ~ T e k n i k ~ d a n ~ I n f o r m a t i k a ~}{ }^{2}$ \\ indahebsi.ac.id 1 \\ nurfia.nos@bsi.ac.id ${ }^{2}$
}

\begin{abstract}
Abstrak
Pengembangan layanan sarana pendidikan online terutama website e-learning saat ini sangat diperlukan untuk menunjang aktivitas pembelajaran jarak jauh khususnya di lingkungan Perguruan Tinggi. Pembuatan website $e$ learning Perguruan Tinggi untuk memfasilitasi pembelajaran jarak jauh perlu diukur efektifitasnya sebagai bahan evaluasi. Tujuan dari penelitian menganalisa dan mengidentifikasikan kepuasan pengguna website $e$ learning MyBest dengan menggunakan metode webqual 4.0. Webqual merupakan salah satu metode pengukuran kualitas website berdasarkan persepsi pengguna akhir. Variabel yang digunakan dalam pengukuran menggunakan webqual 4.0. adalah kegunaan (usability) informasi (information), interaksi layanan (interaction service) dan kepuasan pengguna (user satisfaction). Kuesioner dalam penelitian ini disusun sesuai dengan indikator webqual 4.0 terdiri dari 23 pertanyaan dan terbagi dalam 4 dimensi berdasar variabel webqual. Berdasarkan hasil pengumpulan dan analisis data dalam penelitian ini, maka dapat disimpulkan bahwa keempat variabel webqual yaitu usability, information quality, dan service interaction quality dan variabel pelengkap user satisfaction pada web e-learning universitas berada pada kategori yang cukup tinggi dengan nilai kepuasan pada kategori puas.
\end{abstract}

Kata Kunci: kualitas website, webqual, elearning, website

\section{Website Quality Measurement Based on Webqual 4.0 Method.}

\section{A Research on MyBest E-learning System UBSI.}

\begin{abstract}
The development of online education service facilities, especially e-learning websites, is currently very much needed to support distance learning activities, especially in tertiary institutions. Making a higher education elearning website to facilitate distance learning needs to be measured its effectiveness as an evaluation material. The purpose of this study is to analyze and identify user satisfaction on the MyBest e-learning website using the webqual 4.0 method. Webqual is a method of measuring the quality of a website based on the perceptions of the end user. The variables used in the measurement use webqual 4.0. are usability quality of information quality, service interaction quality and user satisfaction. The questionnaire in this study was arranged according to the webqual 4.0 indicator consisting of 23 questions and was divided into 4 dimensions based on the webqual variable. Based on the results of data collection and analysis in this study, it can be concluded that the four webqual variables, namely usability, information quality, and service interaction quality and the complementary variables of user satisfaction on the university's e-learning web are in a fairly high category with satisfaction scores in the satisfied category.
\end{abstract}

Keywords: website quality, webqual, elearning, website,

\section{Pendahuluan}

Dampak terjadinya pandemi Covid-19 sangat berpengaruh terhadap banyak fakrtor kehidupan tidak terkecuali faktor pendidikan. Berdasarkan Surat Edaran Menteri Pendidikan dan Kebudayaan nomor 4 tahun 2020 tentang pelaksanaan kebijakan pendidikan dalam masa darurat penyebaran Coronavirus Disease (Covid-19) menghimbau seluruh peserta maupun penyelenggaran pendidikan untuk melakukan proses Belajar dari Rumah melalui pembelajaran daring/ jarak jauh. Pandemi Covid19 yang telah berlangsung lebih dari 1 tahun menuntut penyeleggaraan pendidikan jarak jauh bagi seluruh elemen 
pendidikan mulai dari peserta didik, guru, dosen, tutor hingga orang tua. Tsunami pembelajaran online telah terjadi hampir di seluruh dunia selama masa pandemi Covid-19 [1]. Pembelajaran jarak jauh yang sebelumnya masih menjadi pembelajaran alternatif yang melengkapi pembelajaran tatap muka dengan adanya pandemi Covid19 menjadi satu-satunya cara penyelenggaraan pendidikan. Pada awal pandemi Covid-19 penyelenggaraan pendidikan jarak jauh masih butuh banyak adaptasi dalam kondisi persiapan yang sangat minim. Seiring berjalannya waktu penyelenggara pendidikan melakukan evaluasi dan juga perbaikan di berbagai fasilitas yang digunakan untuk melakukan pembelajaran jarak jauh.

Beberapa media pembelajaran online yang bisa dijadikan pilihan diantaranya, yaitu [2]

a. Media Pembelajaran Online yang pertama dan paling banyak digunakan adalah whatsapp group.

b. Media Pembelajaran Online selanjutnya berasal dari google, yaitu google suite for education.

c. Media Pembelajaran Online selanjutnya adalah ruangguru.

d. Media Pembelajaran Online yang bisa dijadikan pilihan selanjutnya adalah zenius.

e. Media Pembelajaran Online yang juga sering digunakan adalah Zoom.

Pada tingkat Perguruan Tinggi penggunaan website e-learning menjadi suatu keniscayaan selain penggunaan media pembelajaran online lainnya. Pengembangan layanan sarana pendidikan online terutama website $e$ learning saat ini sangat diperlukan untuk menunjang aktivitas pembelajaran jarak jauh khususnya di lingkungan Perguruan Tinggi. E-learning menjadi suatu kebutuhan dalam bidang pendidikan. Dimana "e" dalam e-learning mengacu pada bagaimana pendidikan didigitalkan sehingga dapat disimpan dalam bentuk elektronik sedangkan "learning" dalam e-learning mengacu pada apa yaitu mencakup konten dan juga metode untuk membantu Siswa memahami konten tersebut. Dalam hal ini $e$ learning juga membantu mencapai tujuan pendidikan dan membantu organisasi dalam membangun ketrampilan yang terkait dengan peningkatan kinerja sumber daya manusia yang ada.[3]. Menurut Daxiang Dai \& Gaofeng Lin Belajar online menuntut peran pendidik mengevaluasi efektivitas dan disesuaikan dengan kebutuhan belajar. Ini penting dilakukan untuk tetap memenuhi aspek pembelajaran seperti proses pengetahuan, moral, keterampilan, kecerdasan dan estetika [4]

Sebuah website terutama untuk perguruan tinggi sangat diperlukan [5]. Pembuatan website e-learning Perguruan Tinggi untuk memfasilitasi pembelajaran jarak jauh perlu diukur efektifitasnya sebagai bahan evaluasi. Universitas Bina Sarana Informatika pada mulanya masih menggunakan LMS open source berbasis Moodle. Penggunaan LMS open source Moodle memiliki beberapa keunggulan diantaranya gratis, keamanan situs cukup terjamin, modul yang dibutuhkan untuk penyelenggaraan e-learning tersedia lengkap seperti menu untuk menambah resource dan juga menu untuk membuat assessment. Penilaian juga tersedia dalam LMS Moodle. Selain kelebihan Moodle juga disertai kekurangan diantaranya membutuhkan sumber daya yang cukup besar berupa kebutuhan hardware terutama untuk server. Modul dalam LMS Moodle lebih kompleks dibandingkan LMS open source lainnya hal ini mengakibatkan dibutuhkannya server yang besar, pada pelaksanaanya tidak semua modul dalam Moodle digunakan. E-learning di Universitas Bina Sarana Informatika awalnya diselenggarakan hanya untuk sebagian mata kuliah saja. Pandemi Covid-19 menuntut penyelenggaraan kuliah e-learning untuk semua mata kuliah secara full online tanpa tatap muka.

Kondisi ini menjadi pertimbangan untuk membuat website e-learning yang lebih fleksibel dan lebih sesuai dengan kebutuhan Universitas. Dan di semester ketiga penyelenggaraan e-learning di masa pandemi Covid-19, Universitas Bina Sarana Informatika meluncurkan website MyBest yang dibuat tanpa menggunakan open source. Kemunculan website e-learning tersebut menimbulkan permasalahan bagaimana caranya mengukur pengaruh kualitas website MyBest terhadap kepuasan pengguna? Berdasarkan latar belakang yang telah penulis paparkan diatas maka tujuan dari penelitian menganalisa dan mengidentifikasikan kepuasan pengguna website $e$ learning MyBest dengan menggunakan metode webqual 4.0

\section{METODE PENELITIAN}

Beberapa penelitian sebelumnya yang menggunakan metode webqual antara lain: Webqual 4.0 digunakan untuk mengukur kualitas website Buka Lapak terhadap kepuasan kosumen pada website Buka Lapak. Data yang digunakan adalah data primer, yaitu dengan menyebar kuesioner menggunakan skala likert dengan 23 pertanyaan kepada 34 responden. Teknik sampel yang digunakan adalah incidental sampling. Data yang diperoleh dan diolah menggunakan SPSS dan dengan menggunakan teknik analisis Regresi Linier Berganda. Berdasarkan hasil penelitian, terdapat pengaruh yang positif dan signifikan terhadap kepuasan konsumen website bukalapak. [6].

Metode Webqual juga dikombinasikan dengan metode IPA (Importance Performance Analysis) dimana IPA berguna dalam menganalisis tingkat kesesuaian berdasarkan persepsi pengguna dengan harapan pengguna. Metode IPA ini juga akan dapat menunjukkan tingkat kesenjangan antara persepsi pengguna dengan harapan pengguna yang selanjutnya digambarkan dalam kuadran IPA. Instrumen penelitian ini menggunakan kuesioner. Populasi dari penelitian ini merupakan masyarakat umum yang sudah pernah mengakses situs web tribunnews.com dengan teknik random sampling. Hasil dari penelitian ini dapat menjadi referensi bagi untuk pengembangan situs web tribunnews.com dan dapat menambah kepustakaan metode webqual dan IPA.[7]. 
Metode webqual juga digunakan untuk mengukur kualitas website Traveloka terhadap keputusan pembelian. Tujuan dari penelitian ini adalah untuk mengetahui pengaruh website quality (webqual 4.0) terhadap keputusan pembelian pada website Traveloka. Pengolahan data dilakukan dengan SPSS 21 dengan teknik analisis Regresi Linier Sederhana dengan mengolah kuesioner dari responden pengguna Traveloka di Kota Bandung, dari pengolahan datatersebut diketahui bahwa variabel website quality berpengaruh signifikan terhadap variabel keputusan pembelian, dimana variabel webiste quality dapat menjelaskan variabel keputusan pembelian sebesar $40,5 \%$, sedangkan $(100-40,5) \%=59,5 \%$ dijelaskan variabel-variabel yang lain.[8].

Metode Webqual dimodifikasi dengan metode Importance Performance Analysis untuk mengukur kualitas layanan website Pusdiklat BK RI Hasil penelitian ini mampu mengintegrasikan kesenjangan hubungan tingkat harapan dan persepsi pengguna terhadap kualitas layanan yang diberikan website Pusdiklat BPK RI berdasarkan persamaan strukturan dan Importance Performance Analysis (IPA) untuk obyek website pemerintah[9].

Webqual merupakan salah satu metode pengukuran kualitas website berdasarkan persepsi pengguna akhir. Webqual ini merupakan pengembangan dari Servqual yang telah banyak digunakan untuk pengukuran kualitas jasa. L. Pitt,R. Watson, C. Kavan dalam [10] mengatakan Webqual dan Servqual memiliki sudut pandang yang berbeda, dimana Servqual fokus pada Sistem Informasi (IS) kualitas layanan dan fokus Webqual kualitas situs web. Webqual ini berbasis pada Quality Function Deployment (QFD) [8]. Webqual (www.webqual.co.uk) didasarkan pada Quality Function Deployment (QFD) terstruktur dan proses disiplin yang menyediakan sarana untuk mengidentifikasi dan membawa suara pelanggan melalui setiap tahap pengembangan dan implementasi produk dan atau layanan. Penerapan QFD dimulai dengan menangkap suara pelanggan menggunakan kata-kata yang berarti bagi pelanggan. Kualitas ini kemudian diumpankan kembali ke pelanggan dan membentuk dasar dari sebuah evaluasi kualitas suatu produk atau layanan. [11].

Pengembangan instrumen webqual dimulai sejak tahun 1998 dan sudah mengalami beberapa kali perubahan hingga versi 4 saat ini. [7]. Menurut Stuart J. Barnes, Kenny Liu, Richard T. Vidgen dalam [10] Versi pertama dari instrumen Webqual (Webqual L 1.0) dikembangkan sebagian dari hasil lokakarya berkualitas yang diadakan dengan siswa yang diminta untuk mempertimbangkan kualitas dari sebuah situs web sekolah bisnis yang sangat baik. Webqual instrumen disempurnakan melalui proses perbaikan berulang menggunakan kuesioner percontohan sebelum dirilis ke populasi yang lebih besar. Instrumen 24 pertanyaan diuji dengan aplikasi dalam domain situs web UK Business School. Analisis data yang dikumpulkan menyebabkan penghapusan satu pertanyaan. Berdasarkan analisis reliabilitas, 23 pertanyaan tersisa dikelompokkan menjadi empat dimensi utama: kemudahan penggunaan, pengalaman, informasi, dan komunikasi dan integrasi.

Pengembangan Webqual 2.0 memerlukan beberapa perubahan signifikan pada instrumen Webqual 1.0 . Dalam rangka memperluas model untuk kualitas interaksi. [2]. Webqual 2.0 terdapat perbaikan pada persepektif interaction dan mengalami perubahan yang signifikan alternatif webqual 1.0 dan mulai dilakukan perbandingan dengan Servqual, diujikan pada domain toko buku oline Amazon, Blackwells dan Internet bookshop dan menghasilkan bahwa tingkat interaktif dari web mempengaruhi pembelian melalui internet. [8]

Webqual 3.0 menggunakan 3 dimensi yaitu kegunaan, kualitas informasi dan kualitas interaksi pelayanan. Ketika Webqual 1.0 begitu kuat pada kualitas informasinya namun kurang kuat pada interaksi layanannya. Begitu juga dengan Webqual 2.0 yang menekankan kualitas interaksi namun menghilangkan beberapa kualitas informasi dari Webqual 1.0. Versi baru dari Webqual 3.0 ini diujicobakan pada domain lelang online. [12]

Pada Webqual 4.0 disusun berdasarkan pada penelitian tiga area yaitu: kualitas informasi dari sistem informasi, kualitas interaksi dan usability dari human computer interaction. Persepsi pengguna terdiri dari dua bagian yaitu persepsi layanan yang diterima (aktual) dan tingkat harapan (ideal), website yang bermutu dapat dilihat dari tingkat persepsi layanan aktual yang tinggi dan kesenjangan antara persepsi aktual dan ideal yang rendah. [8]

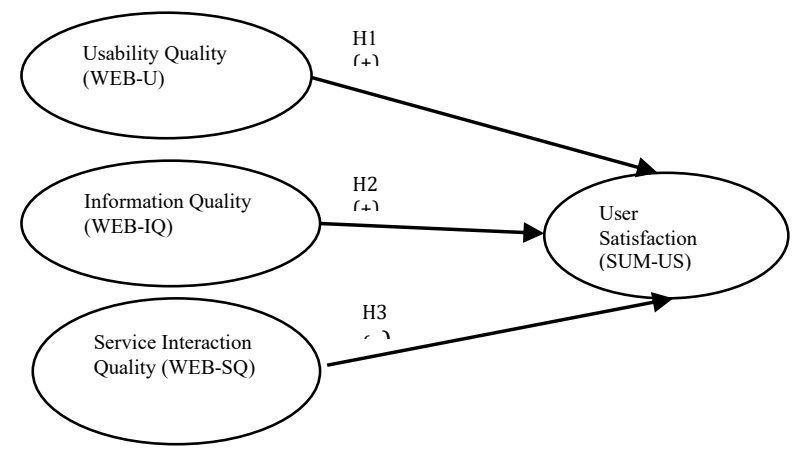

Gambar 1. Model Konseptual Webqual 4.0

Model konseptual diatas menggambarkan hipotesis bahwa terdapat hubungan positif antara kegunaan, informasi dan interaksi layanan dengan kepuasan pengguna. Keempat variabel diatas menjadi variabel dalam penelitian ini. Adapun indikator dari masingmasing variabel diatas, adalah:

1. Usability Quality (Kegunaan)

Usability Quality adalah mutu atau kualitas yang terkait dengan website, mulai dari tampilan, kemudahan dalam navigasi, peletakan informasi, kesesuaian tampilan dengan jenis website. Desain yang menarik dan juga kemudahan dalam menggunakan menjadi penunjang bagi pengguna 
website untuk mengakses dan mengunjungi website secara intens.

2. Information Quality (Kualitas Informasi)

Kualitas informasi bisa dilihat dari pantas atau tidaknya informasi yang ditampilakn di website, apakah informasi yang disajikan dapat dipercaya dan memiliki akurasi yang tepat.

3. Service Interaction Quality (Kualitas Interaksi Layanan)

Kualitas interaksi adalah mutu dari interaksi layaan yang diterima oleh pengguna ketika mengakses website yang terwujud dalam bentuk kepercayaan dan empati.

4. User Satisfaction /Overall (Kepuasan Pengguna/ Keseluruhan)

Variabel terakhir ini merupakan variabel dependen yang menunjukan tampilan website secara keseluruhan baik.

Metode yang digunakan dalam penelitian ini adalah dengan cara menyebarkan kuesioner yang terdiri dari beberapa pertanyaan yang diajukan dalam bentuk formulir online. Skala pengukuran yang digunakan dalam penelitian ini adalah empat poin skala Likert. Pengguna akan diminta menilai website untuk kualitas masingmasing menggunakan skala mulai dari 1 (sangat tidak setuju) hingga 4 (sangat setuju). Skala sengaja dibuat genap untuk menghindari kecenderungan responden yang besikap netral [13].

\section{HASIL DAN PEMBAHASAN}

Website MyBest Elearning UBSI mulai digunakan pada bulan Maret 202, website e-learning pada semester sebelumnya masih berbasis open source moodle kemudian dirubah menggunakan proprietary software yang dirancang dan dibangun oleh staff IT UBSI menyesuaikan dengan kebutuhan Universitas.

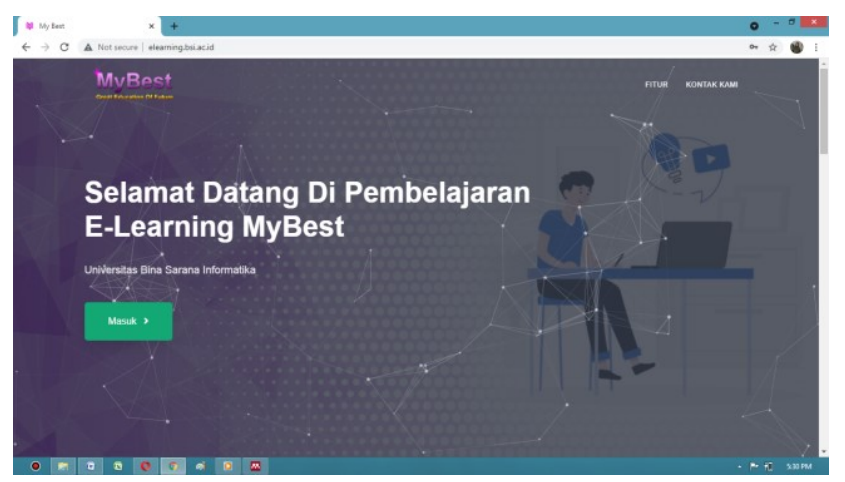

Gambar 2. Tampilan Home MyBest
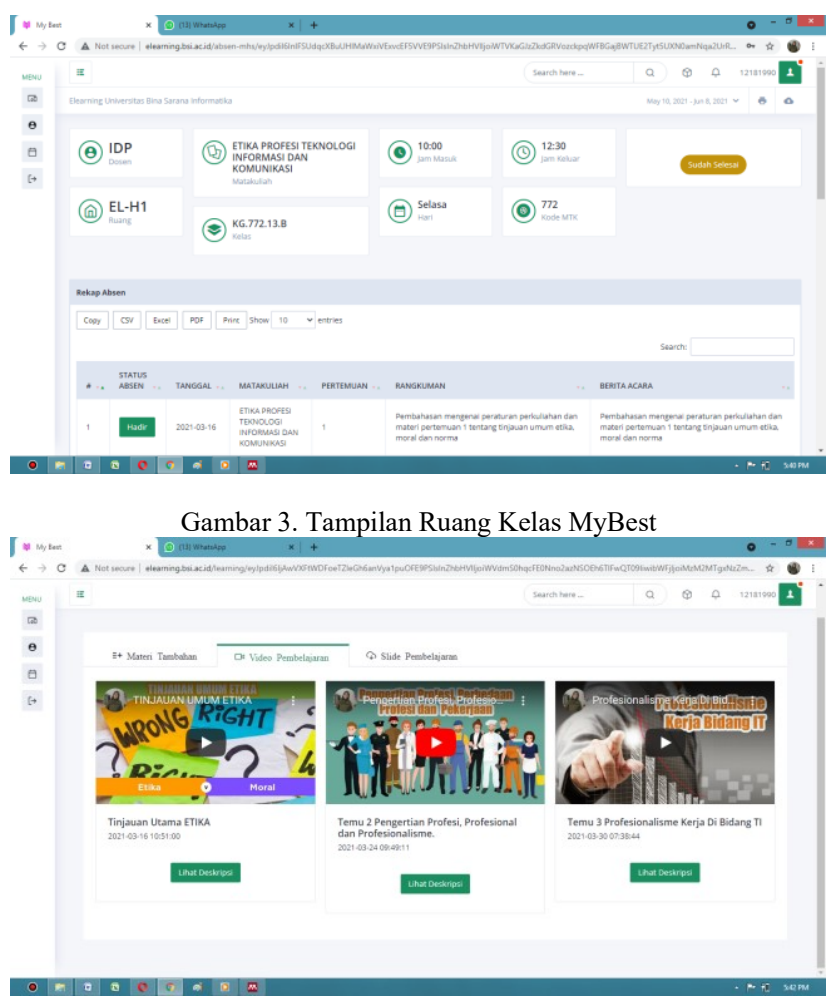

Gambar 4. Tampilan Ruang Materi Mata Kuliah MyBest

Tahapan dari perancangan kuesioner adalah menenukan pertanyaan tentang biodata responden dan pertanyaan yang diambil dari indikator-indikator variabel penelitian[14]. Kuesioner dalam penelitian ini disusun sesuai dengan indikator webqual 4.0 terdiri dari 23 pertanyaan dan terbagi dalam 4 dimensi.

Tabel 1. Kuesioner berdasarkan indikator Webqual 4.0

\begin{tabular}{|c|c|c|c|}
\hline Dimensi & $\begin{array}{l}\text { Webqual } 4.0 \\
\text { Item }\end{array}$ & $\begin{array}{l}\text { Pertanyaan } \\
\text { dalam } \\
\text { Kuesioner }\end{array}$ & Item \\
\hline \multirow[t]{5}{*}{$\begin{array}{l}\text { Kualitas } \\
\text { Kegunaan } \\
\text { (Usability } \\
\text { Quality) }\end{array}$} & $\begin{array}{l}\text { 1. Pengguna } \\
\text { merasa mudah } \\
\text { untuk } \\
\text { mempelajari } \\
\text { pengoperasian } \\
\text { website }\end{array}$ & $\begin{array}{l}\text { 1. Apakah } \\
\text { website } e^{-} \\
\text {learning.bsi.ac.i } \\
\text { d versi terbaru } \\
\text { (MyBest) } \\
\text { mudah untuk } \\
\text { dioperasikan? }\end{array}$ & Q1 \\
\hline & $\begin{array}{l}2 . \quad \text { Interaksi } \\
\text { pengguna } \\
\text { dengan website } \\
\text { jelas dan mudah } \\
\text { di mengerti. }\end{array}$ & $\begin{array}{l}2 . \quad \text { Apakah } \\
\text { pengguna } \\
\text { mudah untuk } \\
\text { berinteraksi } \\
\text { didalam } \\
\text { website? }\end{array}$ & Q2 \\
\hline & $\begin{array}{l}3 . \quad \text { Pengguna } \\
\text { merasa mudah } \\
\text { untuk } \\
\text { bernavigasi } \\
\text { dalam website. }\end{array}$ & $\begin{array}{l}3 . \quad \text { Apakah } \\
\text { mudah untuk } \\
\text { bernavigasi atau } \\
\text { menemukan } \\
\text { menu/link di } \\
\text { dalam website? }\end{array}$ & Q3 \\
\hline & $\begin{array}{l}\text { 4. Pengguna } \\
\text { merasa website } \\
\text { mudah untuk } \\
\text { digunakan. }\end{array}$ & $\begin{array}{l}\text { 4. Apakah } \\
\text { website mudah } \\
\text { digunakan? }\end{array}$ & \\
\hline & 5. Website & Apakah & Q5 \\
\hline
\end{tabular}




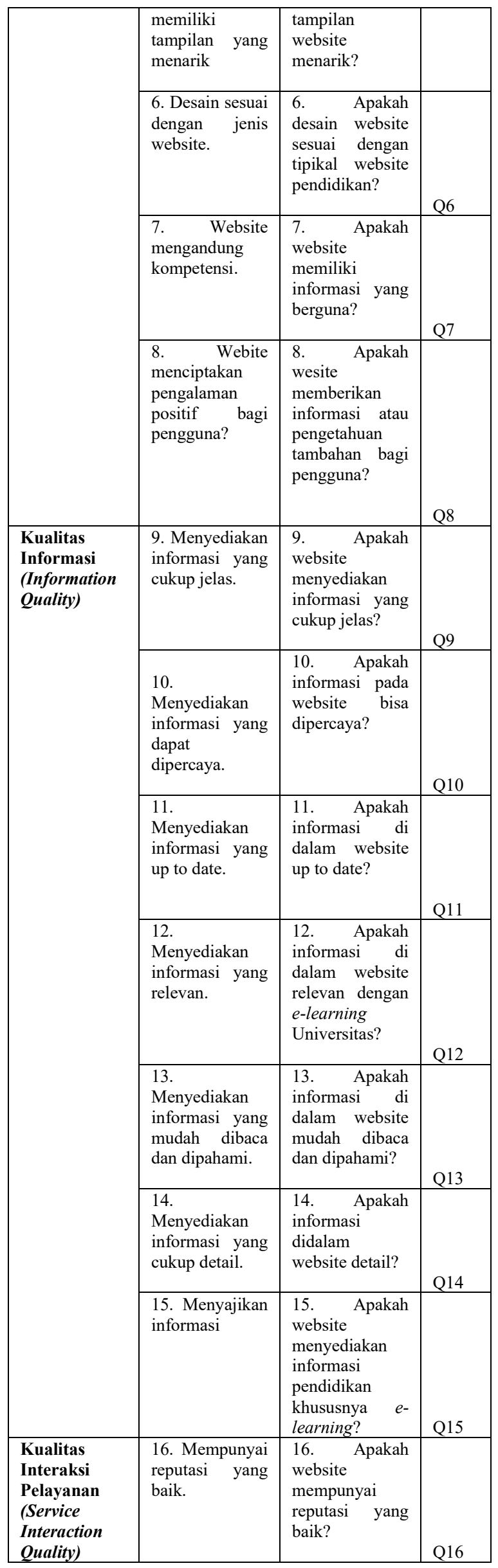

\begin{tabular}{|c|c|c|c|}
\hline & $\begin{array}{l}17 . \\
\text { Mendapatkan } \\
\text { keamanan } \\
\text { untuk } \\
\text { melengkapi } \\
\text { transaksi. }\end{array}$ & $\begin{array}{l}17 . \quad \text { Apakah } \\
\text { pengguna } \\
\text { merasa aman } \\
\text { ketika } \\
\text { melakukan } \\
\text { aktivitas di } \\
\text { dalam website? }\end{array}$ & Q17 \\
\hline & $\begin{array}{l}\text { 18. Rasa aman } \\
\text { dalam } \\
\text { menyampaikan } \\
\text { data pribadi. }\end{array}$ & $\begin{array}{l}\text { 18. Apakah } \\
\text { pengguna } \\
\text { merasa aman } \\
\text { dalam } \\
\text { menyampaikan } \\
\text { data pribadi? }\end{array}$ & Q18 \\
\hline & $\begin{array}{l}\text { 19. Kemudahan } \\
\text { untuk menarik } \\
\text { minat dan } \\
\text { perhatian. }\end{array}$ & $\begin{array}{l}19 . \quad \text { Apakah } \\
\text { website } \\
\text { menarik untuk } \\
\text { dikunjungi? }\end{array}$ & Q19 \\
\hline & $\begin{array}{l}20 . \quad \text { Adanya } \\
\text { suasana } \\
\text { komunitas. }\end{array}$ & $\begin{array}{l}\text { 20Apakah } \\
\text { terdapat } \\
\text { suasana } \\
\text { komunitas di } \\
\text { dalam website } \\
\text { (diskusi/ } \\
\text { bertukar } \\
\text { pendapat)? }\end{array}$ & Q20 \\
\hline & $\begin{array}{l}\text { 21. Kemudahan } \\
\text { untuk memberi } \\
\text { masukan (feed } \\
\text { back). }\end{array}$ & $\begin{array}{l}21 . \quad \text { Apakah } \\
\text { mudah dalam } \\
\text { memberi } \\
\text { masukan (feed } \\
\text { back) ke } \\
\text { pengembang } \\
\text { website/ } \\
\text { Universitas? }\end{array}$ & Q21 \\
\hline & $\begin{array}{l}22 . \quad \text { Tingkat } \\
\text { kepercayaan } \\
\text { yang tinggi atas } \\
\text { informasi yang } \\
\text { disampaikan } \\
\text { website }\end{array}$ & $\begin{array}{l}22 . \quad \text { Apakah } \\
\text { informasi yang } \\
\text { disampaikan } \\
\text { website bisa } \\
\text { dipercaya? }\end{array}$ & Q22 \\
\hline $\begin{array}{l}\text { Keseluruhan } \\
\text { (User } \\
\text { Satisfaction) }\end{array}$ & $\begin{array}{lr}23 . & \text { Pendapat } \\
\text { secara } & \text { umum } \\
\text { tentang } & \text { website } \\
\text { ini } & \end{array}$ & $\begin{array}{lr}23 . & \text { Apakah } \\
\text { anda } & \text { merasa } \\
\text { puas } & \text { dengan } \\
\text { fasilitas } & \text { yang } \\
\text { terdapat } & \text { di } \\
\text { website } & \\
\text { MyBest? } & \\
\end{array}$ & Q23 \\
\hline
\end{tabular}

Populasi adalah keseluruhan subyek penelitia.[15]. Objek penelitian dalam penelitian ini adalah mahasiswa pengguna website elearning, dari beragam semester dan jurusan.

\section{Usability Quality}

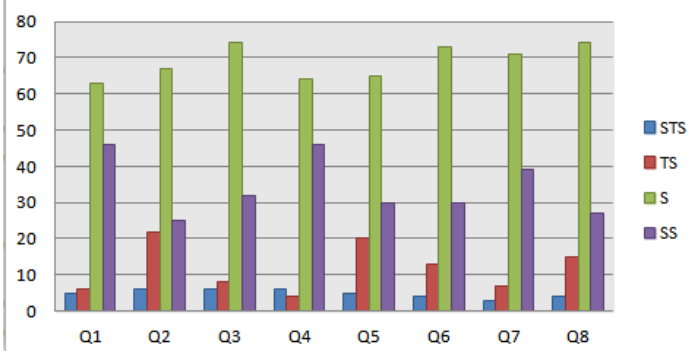

Gambar 5. Grafik Kuesioner Variabel Usability Quality 
Pada dimensi Kualitas Kegunaan (Usability Quality) respon terhadap kuesioner memperlihatkan bahwa sebagian besar mahasiswa merasa Setuju bahwa website memiliki kualitas kegunaan yang baik.yaitu kurang lebih sebanyak 0.04 responden menyatakan Sangat Tidak Setuju, 0.1 responden menyatakan setuju, 0,57 responden menyatakan setuju dan 0.29 responden menyatakan Sangat Setuju.

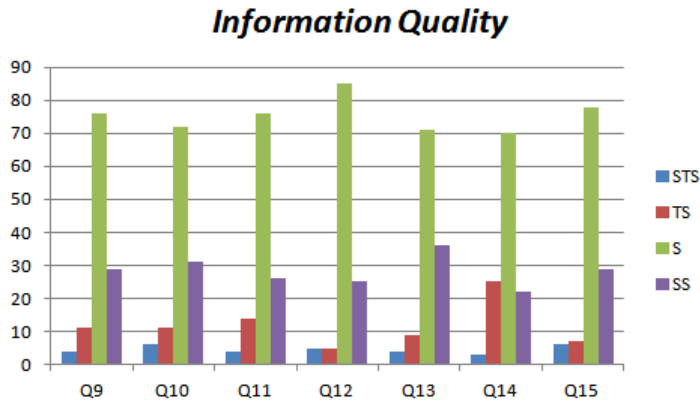

Gambar 6. Grafik Kuesioner Variabel Information Quality

Pada dimensi Kualitas Informasi (Information Quality) respon terhadap kuesioner memperlihatkan bahwa sebagian besar mahasiswa merasa Setuju bahwa website memiliki kualitas kegunaan yang baik.yaitu kurang lebih sebanyak 0.04 responden menyatakan Sangat Tidak Setuju, 0.1 responden menyatakan setuju, 0,63 responden menyatakan setuju dan 0.24 responden menyatakan Sangat Setuju.

\section{Service Interaction Quality}

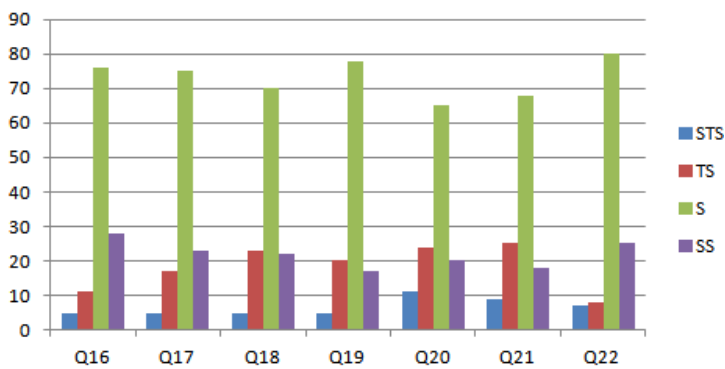

Gambar 7. Grafik Kuesioner Variabel Service Interaction Quality

Pada dimensi Kualitas Interaksi Layanan (Service Interaction Quality) respon terhadap kuesioner memperlihatkan bahwa sebagian besar mahasiswa merasa Setuju bahwa website memiliki kualitas kegunaan yang baik.yaitu kurang lebih sebanyak 0.006 responden menyatakan Sangat Tidak Setuju, 0.16 responden menyatakan setuju, 0,61 responden menyatakan setuju dan 0.17 responden menyatakan Sangat Setuju.
Satisfaction Quality

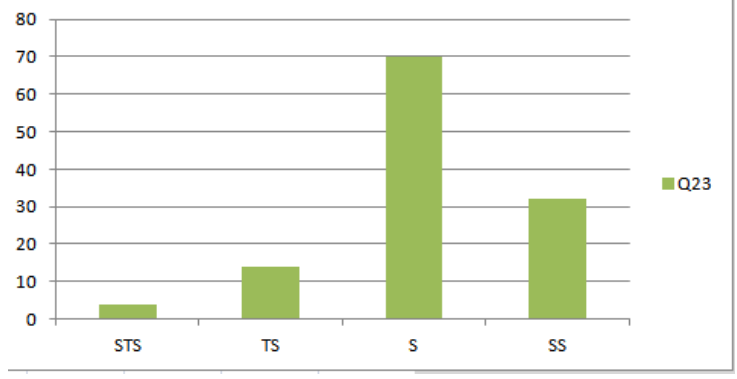

Gambar 5. Grafik Kuesioner Variabel Satisfaction Quality

Pada dimensi Kepuasan Pengguna (Satisfaction Quality) respon terhadap kuesioner memperlihatkan bahwa sebagian besar mahasiswa merasa Setuju bahwa website memiliki kualitas kegunaan yang baik.yaitu kurang lebih sebanyak 0.03 responden menyatakan Sangat Tidak Setuju, 0.12 responden menyatakan setuju, 0,58 responden menyatakan setuju dan 0.27 responden menyatakan Sangat Setuju.

Data kuesioner dalam bentuk excel diimport ke dalam software pengolahan data statistik JASP versi 0.14.1 [16] JASP (Jeffreys's Amazing Statistics Program) adalah program pengolahan data statistik open source yang gratis dan mudah digunakan. Untuk melihat hasil secara lebih rinci data diolah berdasarkan klasifikasi 4 variabel yang digunakan. Kuadran 1 menunjukan skala STS (Sangat Tidak Setuju, kuadran 2 (Tidak Setuju), 3(Setuju), 4(Sangat Setuju).

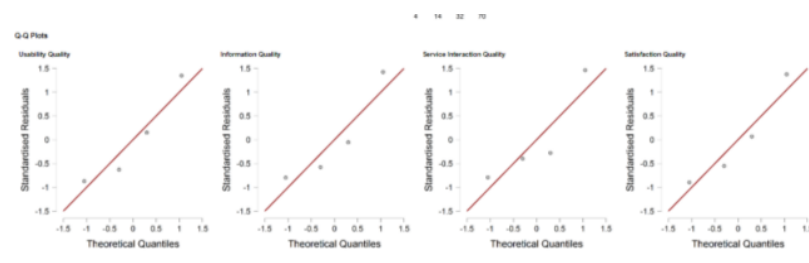

Gambar 8. Perbandingan QQ Plots 4 varibel webqual.

Pada perbandingan 4 variabel webqual diatas dapat dilihat kesamaan pola dimana tiap variable yaitu usability, information quality, dan service interaction quality dan variabel pelengkap user satisfaction menunjukan grafik dengan tingkat kepuasan cukup tinggi yaitu SETUJU bahwa kualitas informasi, kualitas layanan interaksi dan kepuasan pelanggan pada website MyBest elearning UBSI baik.

\section{KESIMPULAN}

Berdasarkan hasil pengumpulan dan analisis data dalam penelitian ini, maka dapat disimpulkan bahwa keempat variabel webqual yaitu usability, information quality, dan service interaction quality dan variabel pelengkap user satisfaction pada web e-learning universita berada pada kategori yang cukup tinggi dengan nilai kepuasan pada kategori puas. Hasil evaluasi pada penelitian memberikan masukan bagi Universitas untuk dapat mempertahankan kualitas kemudahan layanan, informasi dan interaksi layanan yang sudah ada. Untuk memberikan daya tarik 
bagi pengguna diperlukan inovasi berkesinambungan terutama dari segi informasi yang harus terus menerus diupdate secara berkala sesuai kebutuhan layanan. Sebagai bahan perbandingan metode webqual yang digunakan dalam pengukuran kualitas website pada penelitian ini bisa digabungkan dengan metode lain. Perbandingan hasil penelitian menggunakan tambahan metode lain dapat memperbanyak referensi dan dapat dilakukan komparasi dengan hasil penelitian saat ini. Selain itu data penelitian pun bisa digunakan yang lebih beragam untuk mendapatkan pembanding yang lebih beragam

\section{UCAPAN TERIMA KASIH}

Akhir kata penulis mengucapkan terimakasih kepada kepada civitas akademika Universitas Bina Sarana Informatika yang telah berpartisipasi karena berkenan menjadi responden pada penelitian kali. Penulis juga mengucapkan terimakasih kepada peneliti yang menjadi bahan referensi pada penelitian kali ini.

\section{DAFTAR PUSTAKA}

[1] K. Goldschmidt and P. D. Msn, "The Covid-19 Pandemic: Technology use to Support the Wellbeing of Children," no. January, 2020.

[2] I. Sanjaya, "Pengukuran Kualitas Layanan Website Kementerian Kominfo dengan menggunakan Webqual 4.0,” $J$ Penelit. IPTEK-KOM, vol. 14, no. 1, pp. 1-14, 2012.

[3] I. Purwandani, "Analisa Tingkat Kesiapan E-Learning (ELearning Readiness) Studi Kasus: AMIK Bina Sarana Informatika Jakarta," Bianglala Inform., vol. 5, no. 2, Jun. 2017.

[4] L. D. Herliandry, N. Nurhasanah, M. E. Suban, and H. Kuswanto, "Pembelajaran Pada Masa Pandemi Covid-19," JTP - J. Teknol. Pendidik., vol. 22, no. 1, pp. 65-70, 2020.

[5] L. A. S. Waluyo, "Mengukur Kualitas Website Universitas Dengan Pendekatan Webqual," Pros. SNST ke-9, pp. 7-12, 2018

[6] D. Fauziah and D. Wulandari, "Pengukuran Kualitas Layanan Bukalapak.com Terhadap Kepuasan Konsumen dengan Metode Webqual 4.0," J. Ilmu Pengetah. Dan Teknol. Komput., vol. 3, no. 2, pp. 173-180, 2018

[7] E. E. Barus, Suprapto, and A. D. Herlambang, "Analisis Kualitas Website Tribunnews.com Menggunakan Metode Webqual dan Importance Performance Analysis," J. Pengemb. Teknol. Inf. dan Ilmu Komput., vol. 2, no. 4, pp. 1483-1491, 2018.

[8] W. Sastika, "Analisis Pengaruh Kualitas Website (WebQual 4.0) Terhadap Keputusan Pembelian pada Website ecommerce Traveloka," Semin. Nas. Teknol. Inf. dan Komun. 2016 (SENTIKA 2016), vol. 2016, no. Sentika, pp. 18-19, 2016.

[9] dan W. W. W. A. Bayu Luhur Wicaksono, Adhi Susanto, "EVALUASI KUALITAS LAYANAN WEBSITE PUSDIKLAT BPK RI MENGGUNAKAN METODE WEBQUAL MODIFIKASIAN DAN IMPORTANCE PERFORMANCE ANALYSIS Bayu Luhur Wicaksono, Adhi Susanto, dan Wing Wahyu Winarno," Media Ekon. Teknol. Inf. Vol. 19 No. 1, vol. 2, no. 2, pp. 21-34, 2002.

[10] J. Tarigan, "User Satisfaction Using Webqual Instrument: A Research on Stock Exchange of Thailand (SET)," J. Akunt. dan Keuang., vol. 10, no. 1, pp. 24-47, 2008.

[11] S. J. Barnes, K. Liu, and R. T. Vidgen, "Global Co-Operation in the New Millennium EVALUATING WAP NEWS SITES THE WEBQUAL/M APPROACH," 9th Eur. Conf. Inf. Syst. Bled, Slov. June 27-29, 2001, pp. 344-355, 2001.

[12] R. Rahmawati and S. Anwar, "Analisis Pengukuran Kualitas Layanan Website LP2M UIN Raden Fatah Palembang Menggunakan Metode Webqual 4.0," J. Intelekt. Keislaman,
Sos. dan Sains, vol. 7, no. 1, pp. 1-10, 2018

[13] G. Permadi, B. Soedijono, and A. Amborowati, "Pengukuran Mutu Website Dinas Pariwisata Pacitan Menggunakan Metode Webqual," J. Inf., vol. 1, no. 2006, pp. 11-17, 2015.

[14] Ahmad Aditiya, "Analisis Pengaruh Kualitas Website Terhadap Kepuasan Pengguna Berdasarkan Metode Webqual Pada Website www.wingscorp.com," 2017.

[15] C. Irawan, "Evaluasi Kualitas Website Pemerintah Daerah Dengan Menggunakan Webqual (Studi Kasus Pada Kabupaten Ogan Ilir)," Sriwij. J. Inf. Syst., vol. 4, no. 2, pp. 488-502, 2012.

[16] J. Team, "JASP." 0.14.1, 2020 